\title{
Pretreatment of Bio-Oil Followed By Upgrading via Esterification to Boiler Fuel
}

\author{
Sathish K. Tanneru, Divya R. Parapati and Philip H. Steele* \\ Department of Sustainable Bioproducts, Mississippi State University, Mississippi State, \\ MS, 39762 \\ *Corresponding author: psteele@ cfr.msstate.edu
}

\begin{abstract}
Bio-oils produced from fast pyrolysis of renewable energy feedstocks are chemically complex organic liquids that contain over 200 different organic compounds. Many of these compounds are oxygenates which result in $40-45 \%$ oxygen content in the bio-oils. Due to this high oxygen content bio-oils have numerous negative properties that include low heating value, high acidity, high water content and variable viscosity. It is universally agreed that for production of a viable fuel pyrolysis bio-oils must be upgraded. Esterification is a viable means to produce a boiler fuel but maximum heating energies remain rather low and amount of alcohol usually added is uneconomic. In this study we tested oxidative pretreatment prior to esterification as a means to both increase heating energy and decrease the amount of alcohol required. The most effective oxidative pretreatment was with application of a combined ozone $/ \mathrm{H}_{2} \mathrm{O}_{2}$ treatment. The esterification of the ozone/ $\mathrm{H}_{2} \mathrm{O}_{2}$ pretreated product produced a boiler fuel with improved yield and better physical/chemical properties compared to direct esterification of bio-oil. As compared to the product from direct esterification of bio-oil the esterified ozone $/ \mathrm{H}_{2} \mathrm{O}_{2}$ pretreated bio-oil provided a $23 \%$ increased boiler fuel yield of $48 \mathrm{wt} \%$; higher heating value was $5.7 \%$ higher at $35.3 \mathrm{MJ} / \mathrm{kg}$.
\end{abstract}

Keywords: Bio-oil, pretreatment, oxidation, boiler fuel and esterification.

\section{Introduction}

Production of renewable fuels is of growing interest due to the ongoing concerns associated with the fossil fuels such as economic, socio-political and environmental. Biomass is an alternative renewable energy source $[1,2]$ and can be converted into liquid fuels through both thermal and biological methods. One of the thermal decomposition methods is fast pyrolysis of lignocellulosic biomass to produce pyrolysis oil that is frequently referred to as bio-oil. Bio-oil conversion to fuels is a potential promising replacement for fossil fuels. Advantages of liquid bio-oil are the ease of transportation and storage. Fast pyrolysis includes heating the biomass at elevated temperatures in the range of 400 to $550{ }^{\circ} \mathrm{C}$ in the absence of oxygen [2-4].

Fast pyrolysis has the potential to convert any biomass type to a liquid fuel. As a fuel, biomass derived bio-oil has environmental advantages when compared to fossil fuels because, on combustion, bio-oil produces half of the $\mathrm{NO}_{\mathrm{x}}$, and negligible quantities of $\mathrm{SO}_{\mathrm{x}}$ emissions and it is $\mathrm{CO}_{2}$ neutral when compared to conventional fuels. Direct utilization of raw bio-oil is limited because of its negative physical and chemical properties such as high acidity, high moisture content, low energy density, immiscibility with petroleum products, and polymerization resulting in increased viscosity upon exposure to heat or during long-term storage. The chemically 
complex mixture of bio-oil contains over 200 different organic compounds [1,3,5]. Many of these are highly reactive oxygenated compounds that are responsible for most of the negative properties of bio-oil. The presence of oxygenated compounds results in typical bio-oil oxygen content of 40-50 wt \%.

Aldehydes are oxygenates that can undergo homo-polymerization, acetalization and oligomerization by reacting with phenols which leads to polymerization that produces high molecular weight thermoplastic resins. The influences of aldehyde polymerization reactions mainly increase the viscosity of bio-oil during storage or from exposure to heat [6-8]. Aldehydes present in the raw bio-oil can be converted to carboxylic acids by subjecting them to oxidation. Scheme 1 symbolizes the conversion of all bio-oil aldehydes to carboxylic acids in the presence of an oxidizing agent reaction pathway $[9,10]$. Most of the research studies on present upgrading technologies such as hydrodeoxygenation (HDO), catalytic cracking and esterification report that these counter-productive aldehyde polymerization reactions that occur during the upgrading process are a major problem that results in coke formation and low product yields [6, 9-13].

$\mathrm{R}-\mathrm{CHO}$

Aldehyde
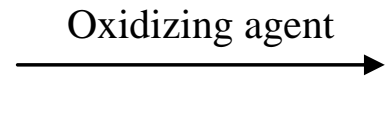

$\mathrm{R}-\mathrm{COOH}$

Carboxylic acid

Scheme. 1. Oxidation pretreatment pathway of bio-oil aldehydes to carboxylic acids [9].

As previously described bio-oil is a complex mixture of different organic compounds containing numerous oxygenated functional groups, including carboxylic acids, aldehydes, ketones, furans, phenols and sugars. These functional groups are a key consideration in the upgrading of bio-oil. Esterification is a potential route to convert the carboxylic acids in bio-oils to esters by reacting them with alcohols to esters in the presence of an acid or base catalyst medium $[12,14,15]$. Esterification performed by reacting carboxylic acid and an alcohol in the presence of an acid catalyst (Fischer esterification reaction) is shown in scheme 2.

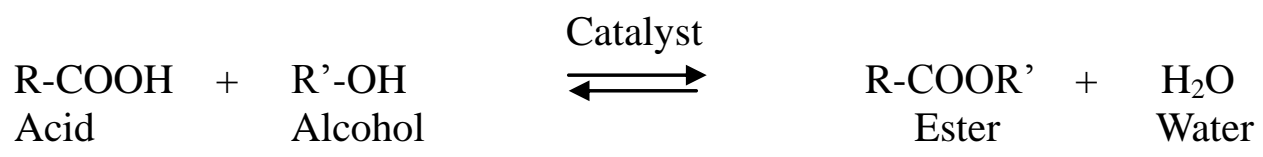

Scheme. 2. Formation of ester by reacting acid and alcohol in presence of catalyst [14].

Furthermore, the conversion of acids also represents a simplification of the currently practiced upgrading processes applied to bio-oil such as hydroprocessing and catalytic pyrolysis. These routes to fuels require high reaction temperatures and hydrogen pressures that are expensive to apply $[13,16]$. The presence of high proportions of acids in bio-oil makes it highly corrosive. It has been demonstrated that esterification via methanol and ethanol will reduce the acidity of the bio-oil, thereby improving bio-oil quality and stability to some extent. To date researchers have used alkaline, resin acid, super critical fluid technology and solid acid catalyst for esterification of bio-oil. Different parameters such as alcohols, catalysts, reaction conditions have been investigated by past researchers using bio-oil or model compounds [17-23].

Zhang et al. (2006) catalyzed the bio-oil esterification reaction with solid acid $40 \mathrm{SiO}_{2} / \mathrm{TiO}_{2}-$ $\mathrm{SO}_{4}{ }^{-2}$ and solid base $30 \mathrm{~K}_{2} \mathrm{CO}_{3} / \mathrm{Al}_{2} \mathrm{O}_{3}-\mathrm{NaOH}$. This model esterification reaction was in a 
molar ratio of 2.5: 1(ethanol: acetic acid). Catalyst was added at $5 \mathrm{wt} \%$ of the reaction solution. Researchers observed that the acid catalyst accelerated the esterification reaction to allow completion in 80 minutes to reach $88 \%$ of equilibrium conversion. The gross calorific value increased from $15.83 \mathrm{MJ} / \mathrm{kg}$ to 23.87 and $24.03 \mathrm{MJ} / \mathrm{kg}$, respectively, for acid and base catalyst. The $\mathrm{pH}$ value of the upgraded bio-oil was lowered to 1.12 by the acid catalyst, while it was increased to 5.93 by the base catalyst [21].

Shanks et al. (2009) studied the impact of reactive oxygenated groups such as aldehydes on the esterification of organic acids using organic-inorganic mesoporous silica functionalized with propylsulfonic acid $\left(\mathrm{SBA}-15-\mathrm{SO}_{3} \mathrm{H}\right)$ catalyst. A bio-oil model compound was prepared by mixing acetaldehyde, propionaldehyde and acetic acid. To examine the effect of aldehydes (acetaldehyde and propionaldehyde) on esterification of acetic acid with ethanol using molar ratio of (ethanol/acetic acid) 2.7, researchers conducted the esterification of acetic acid with and without aldehydes at three different temperatures of $100{ }^{\circ} \mathrm{C}, 70{ }^{\circ} \mathrm{C}$ and $50{ }^{\circ} \mathrm{C}$. The conversion of acetic acid to ethyl esters was not affected by the presence of aldehydes at $100{ }^{\circ} \mathrm{C}$. However, at $70{ }^{\circ} \mathrm{C}$ and $50{ }^{\circ} \mathrm{C}$, the acetic acid to esters conversion in the absence of aldehydes was higher than when aldehydes were present. They also found that the impact of aldehydes on esterification of acetic acid at $50{ }^{\circ} \mathrm{C}$ was even higher when compared at $70{ }^{\circ} \mathrm{C}$. At $70{ }^{\circ} \mathrm{C}$, the acetic acid conversion to esters in the presence of aldehydes was lowered by $6 \%$ when compared to the same reaction without aldehydes. At $50{ }^{\circ} \mathrm{C}$, the acetic acid conversion in the presence of aldehydes was lowered by $28 \%$ when compared to the same reaction without aldehydes. It was also observed that excess of ethanol was consumed due to the formation of acetals by acetalization reactions in the presence of aldehydes. Researchers concluded that there is a significant effect of aldehydes and temperatures on the esterification of carboxylic acids [12].

Wang et al. (2010) studied catalytic esterification of both model compound and bio-oil with 732 and NKC-9 type ion exchange resins as esterification catalysts. The catalytic activity of resins was first investigated by model compound reaction of acetic acid and methanol at a temperature of 70 and $50{ }^{\circ} \mathrm{C}$ for $5 \mathrm{~h}$ with $10 \mathrm{wt} \%$ of catalyst. The acetic acid conversion at a temperature of $70{ }^{\circ} \mathrm{C}$ with 732 resin catalyst showed slightly higher activity compared to NKC-9 catalyst. The esterification of bio-oil with methanol for both 732 and NKC-9 resin catalysts was performed in a batch reactor with a bio-oil to methanol ratio of 1:2. Bio-oil esterification experiments were conducted at a temperature of $50{ }^{\circ} \mathrm{C}$ for $5 \mathrm{~h}$ with $10 \mathrm{wt} \%$ of catalyst. The esterified bio-oil acid values decreased by $88.5 \%$ and $86.0 \%$, calorific values increased by $32.3 \%$ and $31.6 \%$, water contents were lowered by $27.7 \%$ and $30.9 \%$; densities were lowered by $21.8 \%$ and viscosities were reduced for both by approximately $97.0 \%$ after esterification by 732 and NKC-9 resin catalysts, respectively [15].

Weerachanchai et al. (2012) investigated the effects of esterification of palm shell bio-oil such as reaction temperature, reaction time, catalyst type, alcohol type and alcohol to carboxylic acid molar ratio on the reaction conversion. The effect of temperature and time was investigated by esterification of bio-oil with 3.25:1 mole ratio of methanol to the acids in bio-oil at temperatures in the range of $25-60{ }^{\circ} \mathrm{C}$ with $5 \mathrm{wt} \%$ of Amberlyst 15 catalyst for $24 \mathrm{~h}$. Results of the effect of temperature showed that as the temperature increased the acid conversion also increased. The reaction conversion sharply increased in the first $1 \mathrm{~h}$ of reaction time to about $40 \%$, followed by a slow increase and started to attain equilibrium after about $12 \mathrm{~h}$ of reaction time. To study the effect of catalyst type, researchers performed the esterification reactions under the same conditions at a temperature of $60{ }^{\circ} \mathrm{C}$ without catalyst and with $5 \mathrm{wt} \%$ of Amberlyst 15 or $\mathrm{H}_{2} \mathrm{SO}_{4}$ catalysts. Esterification conversion without catalyst gave only $13.13 \%$ but with 
Amberlyst 15 it increased to $86.87 \%$ and with $\mathrm{H}_{2} \mathrm{SO}_{4}$ catalyst conversion increased dramatically to $93.75 \%$. The effect of alcohol type was investigated using methanol and ethanol at the same reaction conditions. Bio-oil upgraded by using methanol exhibited a much higher conversion of $73.39 \%$ compared with the use of ethanol which gave only $54.80 \%$ conversion. Relatively high HHVs in the range of $23.10-23.78 \mathrm{MJ} / \mathrm{kg}$ were obtained with methanol, whereas the upgraded bio-oil using ethanol gave a slightly higher value of $25.40 \mathrm{MJ} / \mathrm{kg}$. Respective physical properties for raw and upgraded bio-oils were densities of 0.79 and $0.80 \mathrm{~g} / \mathrm{cm}^{3}$, viscosities of 0.58 and 1.22 $\mathrm{mm}^{2} / \mathrm{s}$, flash points of 11 and $14{ }^{\circ} \mathrm{C}$ and $\mathrm{pH}$ values of 6.63 and 6.58 [14].

$\mathrm{Xu}$ et al. (2011) introduced an ozone oxidation method for bio-oil derived from rice-husks. A laboratory scale ozone generator provided ozone at $5 \mathrm{~g} / \mathrm{h}$. The oxidation pretreatment reactions were performed by continuously introducing the ozone into a batch glass reactor at a temperature range of $20-22{ }^{\circ} \mathrm{C}$ for $10 \mathrm{~h}$. This oxidized product was then esterified by addition of $100 \%$ butanol at $116{ }^{\circ} \mathrm{C}$ for $3-4 \mathrm{~h}$. This oxidation of bio-oil followed by esterification changed the characteristics of the esterified product. The gross calorific value of raw bio-oil $(9.5 \mathrm{KJ} / \mathrm{g})$ increased to $27.4 \mathrm{KJ} / \mathrm{g}$ for esterified bio-oil without pretreatment; for esterified bio-oil with pretreatment the increase was to $25.0 \mathrm{KJ} / \mathrm{g}$ [9].

Considerable research has been performed on the esterification of raw bio-oils to produce upgraded biofuels. Based on previous studies esterification of raw bio-oil produces esters with maximum heating value of $24-28 \mathrm{MJ} / \mathrm{kg}$ and also the consumption of alcohols to raw bio-oil ratio has been relatively high. Zhang esterified bio-oil with a 2.5:1 (250\%) alcohol addition. Mahfud esterified bio-oil with a $100 \%$ addition of butanol [16]. Moens noted that a typical biooil required 10-14 mol of alcohol per kilogram of bio-oil to completely esterify aldehydes, acids and ketones [16,17,21]. Reduction of alcohol required for esterification may be reduced if the aldehydes and ketones are converted to carboxylic acids prior to esterification. Our current study tests an oxidation pretreatment method applied to raw bio-oil to convert aldehydes and ketones to carboxylic acids followed by esterification to improve the raw bio-oil characteristics. The oxidative pretreatment followed by esterification increased HHV, decreased acidity and lowered water content and viscosity. This product is considered suitable for boiler fuel based on the high HHV value.

\section{Experimental}

\subsection{Materials}

\subsubsection{Catalysts}

$\mathrm{Ru} / \gamma-\mathrm{Al}_{2} \mathrm{O}_{3}(0.5 \% \mathrm{Ru})$ catalyst was obtained from Acros organics. Hydrogen peroxide $\left(\mathrm{H}_{2} \mathrm{O}_{2}\right)$ $50 \mathrm{wt} \%$ solution in water was obtained from Sigma-Aldrich. All chemicals were used with no further purification. Ozone used in this study to oxidize the raw bio-oil was produced by pumping the pure oxygen (obtained from nexAir) through an OZV-8 ozone generator with $8 \mathrm{~g} / \mathrm{h}$ ozone flow directly into the pretreatment reaction vessel.

\subsubsection{Bio-oil}

Bio-oil required for this research was produced from loblolly pine wood chips with a size of 1-3 mm and moisture content of 8-10\% on dry-weight basis. Bio-oil was produced by the fast pyrolysis process performed at a temperature of $450{ }^{\circ} \mathrm{C}$ with nitrogen carrier gas at a biomass utilization rate of $7 \mathrm{~kg} / \mathrm{h}$ with an auger-feed pyrolysis reactor located in the Department of 
Sustainable Bioproducts, Mississippi State University (MSU). The MSU auger fast pyrolyzer produced $60-65 \mathrm{wt} \%$ of liquid product, $10-15 \%$ of non-condensable gases and $20-25 \%$ of char on a dry biomass weight basis.

\subsection{Methods}

\subsubsection{Oxidation (pretreatment) of raw bio-oil}

All pretreatments of raw bio-oil were performed in a $250 \mathrm{ml}$ round bottom flask equipped with an electronic stirrer in a closed hood; oxidation reactions were performed at ambient temperature and pressure. The oxidation of raw bio-oil was tested with three oxidation reactants: $\mathrm{H}_{2} \mathrm{O}_{2}$ alone, ozone alone and a combination of ozone and $\mathrm{H}_{2} \mathrm{O}_{2}$ (ozone/ $\mathrm{H}_{2} \mathrm{O}_{2}$ ). The best pretreatment oxidant was deemed to be that with highest production of carboxylic acids as measured by magnitude of acid value (AV). The oxidation of raw bio-oil by $\mathrm{H}_{2} \mathrm{O}_{2}$ alone was performed by addition of $10 \mathrm{wt} \%$ of commercial $50 \mathrm{wt} \% \mathrm{H}_{2} \mathrm{O}_{2}$ solution in water followed by stirring for $60 \mathrm{~min}$ at room temperature. The oxidation of raw bio-oil by ozone alone was performed by pumping 3-5 psig ozone into the pretreatment reaction vessel followed by stirring for $60 \mathrm{~min}$ at room temperature. The oxidation of raw bio-oil was conducted by a mixture of ozone $/ \mathrm{H}_{2} \mathrm{O}_{2}$ by pumping 3-5 psig ozone into the pretreatment reaction vessel containing a mixture of raw bio-oil and $10 \mathrm{wt} \%$ of commercial $50 \mathrm{wt} \% \mathrm{H}_{2} \mathrm{O}_{2}$ solution in water followed by stirring for $60 \mathrm{~min}$ at room temperature. It was observed that the dark colored raw bio-oil changed to a reddish brown color during ozone $/ \mathrm{H}_{2} \mathrm{O}_{2}$ pretreatment. This color change was not noticed for ozone or $\mathrm{H}_{2} \mathrm{O}_{2}$ oxidation when each was applied separately. The pretreatment with the highest AV was selected as having the best performance because it indicated the highest production of carboxylic acids, which in turn represented an increased conversion of aldehydes and ketones.

\subsubsection{Esterification of oxidized bio-oil}

Esterification was performed in a stainless steel, high-pressure batch autoclave reactor equipped with an overhead magnetic stirrer, a pressure indicator with a maximum capacity of 5000 psig and a thermocouple for temperature monitoring in the range of $0-500{ }^{\circ} \mathrm{C}$. The autoclave was equipped with an electrical heating and cooling system to control the temperature inside the reactor. The esterification was performed by addition of $20 \mathrm{wt} \%$ of butanol to the ozone $/ \mathrm{H}_{2} \mathrm{O}_{2}$ pretreated bio-oil in the presence of a mixture of $\mathrm{Ru} / \gamma-\mathrm{Al}_{2} \mathrm{O}_{3}(4 \mathrm{wt} \%)$ and potassium carbonate $(4 \mathrm{wt} \%)$ catalyst at a temperature of $340{ }^{\circ} \mathrm{C}$ and under pressurized hydrogen at $2 \mathrm{MPa}$ for $90 \mathrm{~min}$. As a control raw bio-oil was also esterified without application of pretreatment by following the same esterification procedure as described above.

In each experiment, once the reaction was complete, the liquid products were cooled to room temperature in the reactor. The mixture was collected in centrifuge test tubes and which were centrifuged to separate the resulting aqueous and organic phases; the time for centrifuging to separation ranged from 2-4 h. Both phases were separated and weighed for mass balance computation. The organic fraction comprised of the higher HHV product suitable for boiler fuel. Yields were calculated by Equation 1 [24].

Yield of boiler fuel $(\mathrm{wt} \%)=(\mathrm{P}(\mathrm{g}) \times 100) /$ bio-oil weight $(\mathrm{g})$

Eq. 1

Where: $\mathrm{P}=$ organic products obtained 


\subsubsection{Data analysis}

The raw bio-oil, pretreated product and boiler fuel were characterized by following ASTM methods. The densities were determined by Anton Parr DMA 35n portable density meter by ASTM D4052 method. Viscosities were determined by Ubbelohde capillary viscometer at $40{ }^{\circ} \mathrm{C}$ water bath temperature by ASTM D445 method. Higher heating values (HHV) were determined by Ika-5000 bomb calorimeter by ASTM D240 method. The acid values (AV) were determined by dissolving $1 \mathrm{~g}$ of bio-oil in $50 \mathrm{ml}$ of 35:65 ratio of isopropanol to water mixtures and titrating to a $\mathrm{pH}$ of 8.5 with $0.1 \mathrm{~N} \mathrm{KOH}$ solution by ASTM D664 method. The $\mathrm{pH}$ values were determined by addition of $1 \mathrm{~g}$ of bio-oil to $50 \mathrm{ml}$ of $35 \%$ of isopropanol mixture. The $\mathrm{pH}$ values were determined by ASTM E70 method. Elemental carbon, hydrogen, and nitrogen were determined by EAI CE-440 elemental analyzer with oxygen content was determined by difference according to ASTM D5291 method. Water content was determined by Karl-Fisher titration by ASTM E203.

\section{Results and Discussion}

In this study we have applied oxidation pretreatment to raw bio-oil and followed by subsequent esterification to produce a product with high HHV suitable for boiler fuel. Figure 1 compares acid values of the pretreated products obtained from 1-h pretreatments of raw bio-oil with ozone alone, $\mathrm{H}_{2} \mathrm{O}_{2}$ alone and the ozone $/ \mathrm{H}_{2} \mathrm{O}_{2}$ combination. Figure 1 indicates that after pretreatment of raw bio-oil with ozone pretreatment the $\mathrm{AV}$ increased from 90.3 of raw bio-oil to $107.7 \mathrm{mg} \mathrm{KOH} / \mathrm{g}$; with $\mathrm{H}_{2} \mathrm{O}_{2}$ pretreatment the $\mathrm{AV}$ increased from 90.3 to $118.3 \mathrm{mg} \mathrm{KOH} / \mathrm{g}$. For the combined ozone $/ \mathrm{H}_{2} \mathrm{O}_{2}$ pretreatment $\mathrm{AV}$ increased from 90.3 to $161.9 \mathrm{mg} \mathrm{KOH} / \mathrm{g}$. The 161.9 $\mathrm{mg} \mathrm{KOH} / \mathrm{g}$ AV for the ozone $/ \mathrm{H}_{2} \mathrm{O}_{2}$ pretreatment represented respective 50.3\% and 36.8\% increases in $\mathrm{AV}$ above the values for the ozone and $\mathrm{H}_{2} \mathrm{O}_{2}$ alone pretreatments.

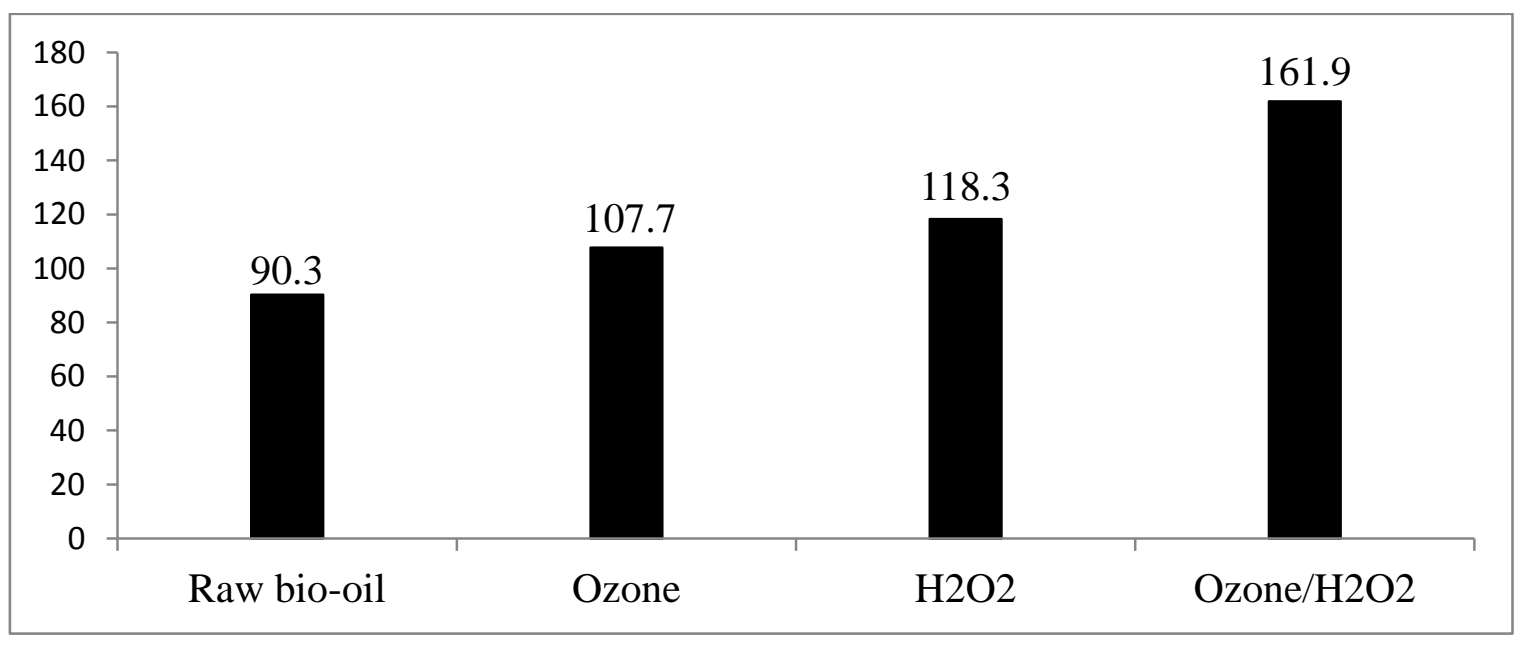

Fig. 1. Effect on $\mathrm{AVs}$ of ozone, $\mathrm{H}_{2} \mathrm{O}_{2}$ and combined ozone $/ \mathrm{H}_{2} \mathrm{O}_{2}$ oxidation pretreatments applied to raw bio-oil over a time period of $1 \mathrm{~h}$.

The high AV of the ozone $/ \mathrm{H}_{2} \mathrm{O}_{2}$ pretreatment indicated the conversion of carbonyl compounds (mainly aldehydes and ketones) and alcohols to carboxylic acids. Therefore, the best pretreatment for oxidation of raw bio-oil, based on highest AV obtained, was by far the 
ozone $/ \mathrm{H}_{2} \mathrm{O}_{2}$ combined pretreatment. For that reason subsequent analyses were performed on the product from this most-promising pretreatment.

Figure 2 compares the FTIR spectra of raw bio-oil and the ozone $/ \mathrm{H}_{2} \mathrm{O}_{2}$ pretreated bio-oil (OPTBO). Characteristic vibrational modes are observed at $1650-1710 \mathrm{~cm}-1$ ( $\mathrm{C}=\mathrm{O}$ stretching) and 3600-3000 cm-1 (HO stretching). It was observed that $\mathrm{C}=\mathrm{O}$ stretching was decreased and $\mathrm{OH}$ stretching was intensified, indicating that carbonyl compounds (mainly aldehydes and ketones) were converted to carboxylic acids.

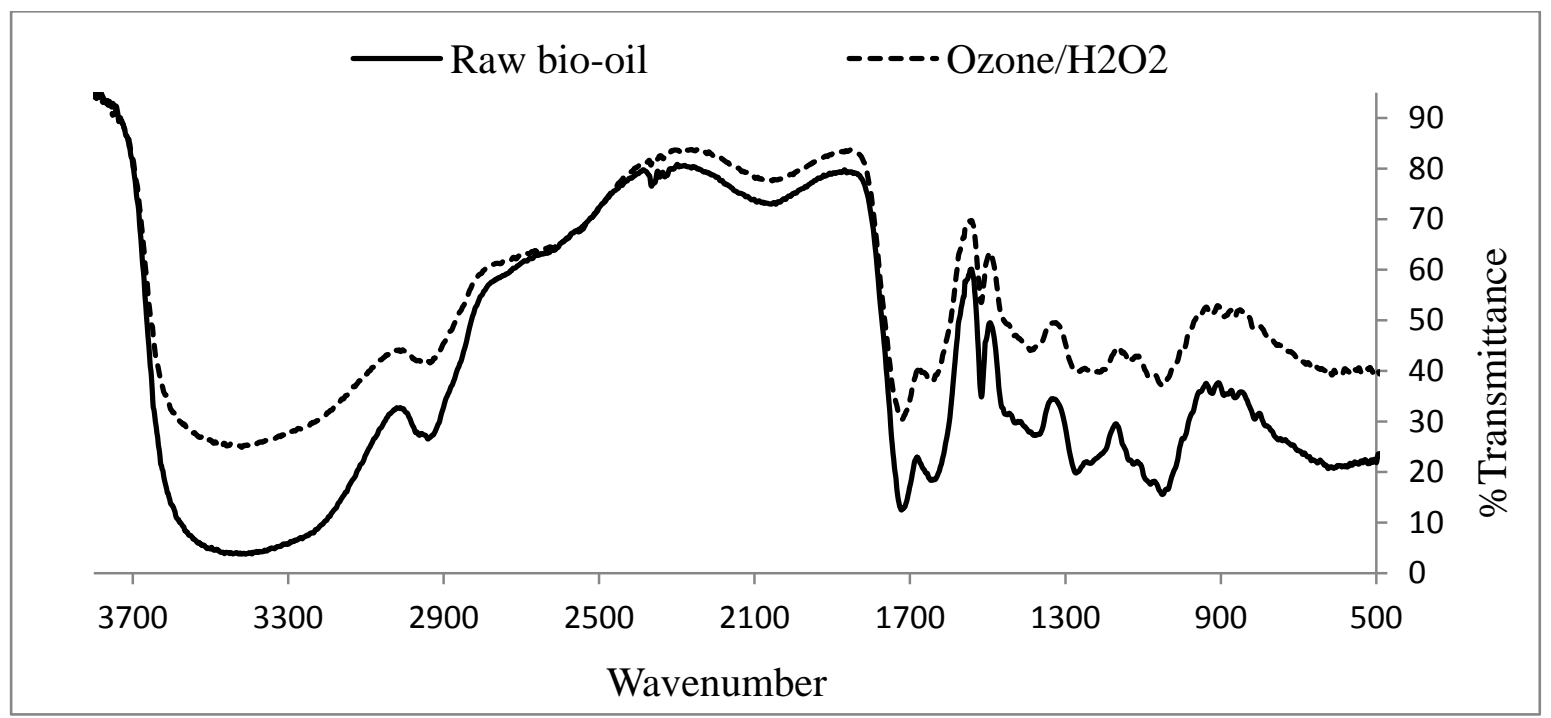

Fig. 2. FTIR spectrum comparison of raw bio-oil and ozone/ $\mathrm{H}_{2} \mathrm{O}_{2}$ pretreated product showing.

Figure 3, shows the effect of combined ozone $/ \mathrm{H}_{2} \mathrm{O}_{2}$ pretreatment on raw bio-oil AV over time and tested at 15 min time intervals. The AV of the combined ozone $/ \mathrm{H}_{2} \mathrm{O}_{2}$ bio-oil treatment at time zero was $110.4 \mathrm{mg} \mathrm{KOH} / \mathrm{g}$; The $\mathrm{AV}$ of raw bio-oil after $1 \mathrm{~h}$ of pretreatment was significantly increased to $161.2 \mathrm{mg} \mathrm{KOH} / \mathrm{g}$. However, the increase in AV was a maximum at a time period of $1 \mathrm{~h}$. After $1 \mathrm{~h}$ the AV remained essentially constant as shown in Figure 3.

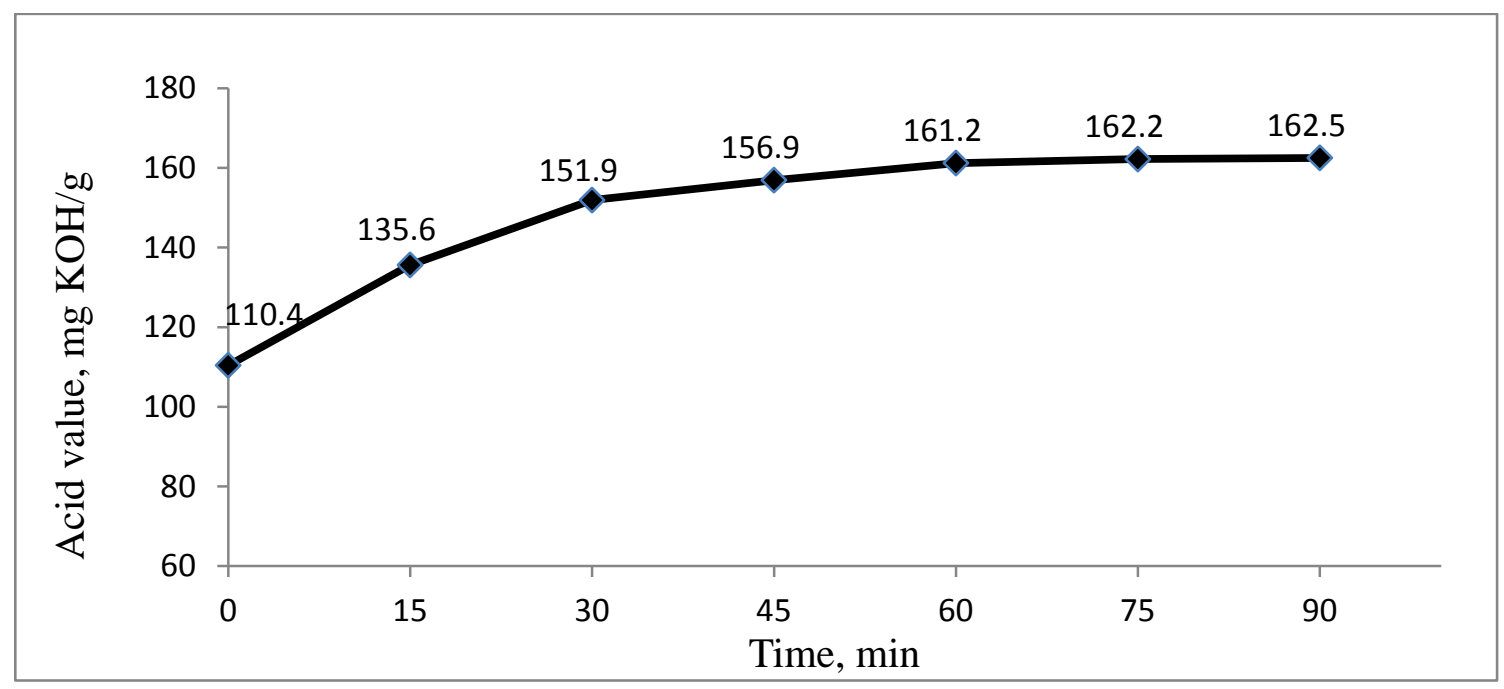


Fig. 3. Effect of ozone/ $\mathrm{H}_{2} \mathrm{O}_{2}$ pretreatment on $\mathrm{AV}$ of raw bio-oil over time as measured at 15-min intervals.

Table 1 shows a comparison of physical and chemical properties of raw bio-oil, ozone $/ \mathrm{H}_{2} \mathrm{O}_{2}$ pretreated bio-oil (OPTBO), raw bio-oil without pretreatment after esterification produced boiler fuel type $1(\mathrm{BF} 1)$ and OPTBO after esterification produced boiler fuel type $2(\mathrm{BF} 2)$ are compared. As shown in Table 1, after pretreatment the AV of OPTBO increased to $165.4 \mathrm{mg}$ $\mathrm{KOH} / \mathrm{g}$ from $90.3 \mathrm{mg} \mathrm{KOH} / \mathrm{g}$ the value of raw bio-oil. The total AV increased by $83.16 \%$, which indicates the oxidation of aldehydes/ketones and alcohols to acids. The viscosity decreased from 12.0 to $9.2 \mathrm{cSt}$, water content increased from 30.4 to $33.5 \%$. The HHV of the oxidized product increased from 16.0 to $16.4 \mathrm{MJ} / \mathrm{kg}$. Density decreased from 1.2 to $1.0 \mathrm{~g} / \mathrm{ml}$ and $\mathrm{pH}$ was reduced to 2.3 from 3.1. Oxygen content increased somewhat from 53.9 to $55.3 \mathrm{wt} \%$. This oxygen content were resulted from both increased acid and water content.

Table 1. Comparison of some physical and chemical properties of raw bio-oil, OPTBO, BF1 and BF2.

\begin{tabular}{|c|c|c|c|c|}
\hline Properties & Raw bio-oil & OPTBO & BF1 & BF2 \\
\hline HHV, MJ/Kg & 16.0 & 16.4 & 33.4 & 35.3 \\
\hline AV (mg KOH/g) & 90.3 & 165.4 & 25.8 & 34.3 \\
\hline Water content (\%) & 30.4 & 33.5 & 4.6 & 3.6 \\
\hline Density, g/ml & 1.2 & 1.0 & 1.0 & 0.9 \\
\hline $\begin{array}{c}\text { Kinematic viscosity, } \\
40^{\circ} \mathrm{C}, \mathrm{cSt}\end{array}$ & 12.0 & 9.2 & 25.9 & 10.1 \\
\hline $\mathrm{pH}$ & 3.1 & 2.3 & 4.4 & 4.2 \\
\hline Elemental analysis (\%) & & & & \\
\hline $\mathrm{C}$ & 38.4 & 37.6 & 71.8 & 71.6 \\
\hline $\mathrm{H}$ & 7.6 & 7.6 & 9.8 & 10.3 \\
\hline $\mathrm{N}$ & 0.2 & 0.2 & 0.4 & 0.3 \\
\hline $\mathrm{O}$ & 53.7 & 54.6 & 17.9 & 17.7 \\
\hline Yield (wt\%) & - & - & 39.0 & 48.0 \\
\hline
\end{tabular}

The raw bio-oil and pretreated product (OPTBO) were then subjected to esterification to produce $\mathrm{BF} 1$ and $\mathrm{BF} 2$, respectively, as described in the esterification method section. The resulting liquid product was comprised of both an organic phase as a top layer and an aqueous phase at the bottom. The organic fraction was separated by centrifuging for 3-4 h followed by separation of the water fraction with a separatory funnel. For the organic fraction of the esterified boiler fuels some physical and chemical properties were determined by ASTM test methods.

Comparing the pretreated product (OPTBO) to the boiler fuel produced from it (BF2) we note that the HHV nearly doubled for the esterified BF2 product with an increase from 16.4 $\mathrm{MJ} / \mathrm{Kg}$ to $35.3 \mathrm{MJ} / \mathrm{Kg}$. The $\mathrm{AV}$ for the BF2 product was dramatically reduced from the OPTBO value of $165.4 \mathrm{mg} \mathrm{KOH} / \mathrm{g}$ to $34.3 \mathrm{mg} \mathrm{KOH} / \mathrm{g}$, a decrease of $382.2 \%$. Water content of the BF2 product was reduced to nearly $10.7 \%$ of the value of $33.5 \%$ for OPTBO to 3.6. Density and viscosity were essentially unchanged when OPTBO was esterified to BF2. Carbon content of BF2 nearly doubled to 71.6 from 37.6 from that of OPTBO. Hydrogen content was $35.5 \%$ higher 
for $\mathrm{BF} 2$ at $71.6 \%$ compared to the $37.6 \%$ of OPTBO. Nitrogen increased from $0.22 \%$ for OPTBO to $0.31 \%$ for $\mathrm{BF} 2$, a $40.9 \%$ increase. BF2 oxygen content was reduced by the esterification of OPTBO with a decrease from 54.6 to $17.7 \%$, a $208.5 \%$ decrease. Therefore, the esterification of OPTBO to produce BF2 substantially increased the quality of its most important characteristics (HHV, AV, water, hydrogen and oxygen content, and $\mathrm{pH}$ value); density and viscosity remain essentially the same. The only negative change was the small increase in nitrogen content.

The esterification of raw bio-oil produced BF1 resulting in a more than $100 \%$ increase in HHV. AV decreased from 90.3 for raw bio-oil to 25.8 for BF1, a $250 \%$ decrease. Water content of the BF1 product was reduced to approximately $15.2 \%$ of the value of 30.4 for raw bio-oil to 4.6. Density was decreased from 1.2 to 1.0 , a decrease of $20 \%$. Viscosity was increased from 12.0 to 25.9 , an increase by $115.8 \%$. Carbon content of BF1 increased to 71.8 from 38.4 for raw bio-oil. Hydrogen content was increased by $28.9 \%$. Nitrogen was increased from 0.2 to 0.4 . BF1 oxygen content was reduced from raw bio-oil, 53.7 to $17.9 \mathrm{wt} \%$, a decrease of $200 \%$.

A comparison of BF1 to BF2 will indicate whether the OPTBO treatment is sufficiently advantageous, or whether simple esterification of raw bio-oil is a better choice. For BF2 the $\mathrm{HHV}$ of $35.3 \mathrm{MJ} / \mathrm{Kg}$ was slightly higher $(5.7 \%)$ than $\mathrm{BF} 1$ which had a value of $33.4 \mathrm{MJ} / \mathrm{Kg}$. AV was higher for the BF2 product. Water content of BF2 was $28 \%$ less than the BF1. Density value of both $\mathrm{BF} 1$ and $\mathrm{BF} 2$ remained essentially unchanged. BF2 viscosity was reduced significantly to 10.1 compared to, BF1 value of 25.9 , a reduction of $156.4 \%$. The esterification of OPTBO compared to esterification of direct raw bio-oil produced the BF2 fuel with improved characteristics in terms of reduced viscosity and water content and increased HHV. The BF2 obtained from OPTBO also produced 9\% higher yield compared to BF1 obtained from direct raw bio-oil esterification. The viscosity value of BF1 is a particular problem as pumping such viscous material into a boiler may be problematic. Based on the increased characteristics in terms of yield, viscosity, $\mathrm{HHV}$, water content it is clear that BF2 is the superior boiler fuel.

The esterification of OPTBO to produce BF2 utilized only $20 \%$ of alcohol to produce a boiler fuel with an $\mathrm{HHV}$ of $35.3 \mathrm{MJ} / \mathrm{kg}$ compared to past researchers who have utilized or recommended alcohol additions of 100 to $250 \%$ or more.

\section{FTIR spectral analysis comparing spectra of raw bio-oil to pretreated and esterified products}

In our study, FTIR spectral data was used to analyze the raw bio-oil, OPTBO and boiler fuels (BF1 and BF2). Characteristic vibrational modes are observed at 1100-1300 cm-1 (C-O stretching), $1710 \mathrm{~cm}-1$ (C=O stretching), 2850-2980 cm-1 (CH stretching, aliphatic) and 3600$3000 \mathrm{~cm}-1$ (OH stretching). From Figure 4, it was evident that after ozone $/ \mathrm{H}_{2} \mathrm{O}_{2}$ pretreatment $\mathrm{C}=\mathrm{O}$ stretching peak was decreased and $\mathrm{OH}$ stretching was intensified. The decreasing of $\mathrm{C}=\mathrm{O}$ stretching peak and increasing of $\mathrm{OH}$ stretching indicate increase in carboxylic acids after ozone $/ \mathrm{H}_{2} \mathrm{O}_{2}$ pretreatment. Furthermore, on esterification the intensity of $\mathrm{CH}$ stretching band dramatically increased and $\mathrm{OH}$ absorption band is significantly decreased due to conversion of carboxylic acids to esters and decrease in water content. As shown in Figure 4, it is clear that the decreasing of $\mathrm{OH}$ stretching peak of $\mathrm{BF} 2$ is significantly higher than $\mathrm{BF} 1$; which implies that conversion of acids to esters and separation of water after esterification of OPTBO was improved compare to the esterification of raw bio-oil. The FT-IR spectral data shown in Figure 4 was in good agreement with the properties shown in Table 1 and Figure 4. 


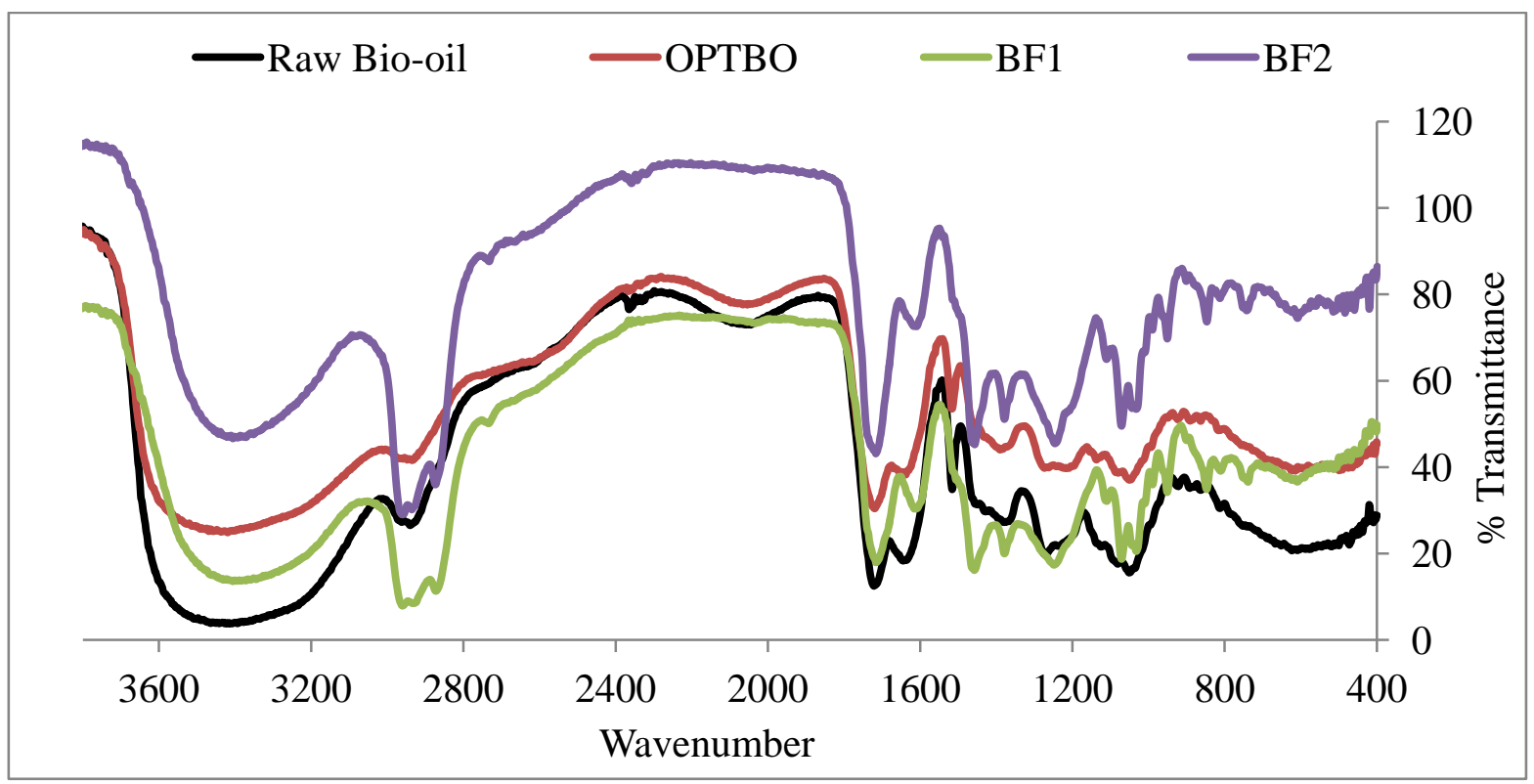

Fig. 4. FTIR spectra comparison between raw bio-oil, OPTBO, BF1 and BF2.

\section{GC-MS chemical compounds analysis of raw bio-oil and BF2.}

Table 2 shows the chemical composition of raw bio-oil and BF2 analyzed by GC-MS. Approximately 50 chemical compounds were identified by GC-MS in both samples. The chemical compound name and their area percentages are given in Table 2. The total area percentages of major fifty compounds present in raw bio-oil and BF2 were $100.0 \%$ and $78.93 \%$, respectively. As shown in Table 2 it is very clear that, BF2 chemical composition as measured by GC-MS area percentage were significantly changed compared to raw bio-oil. The carboxylic acids present in the raw bio-oil decreased from the 9.8 area\% to 1.2 area\% for $\mathrm{BF} 2$, a reduction of $87.8 \%$. Ester and ether compounds of BF2 increased to 22.63 area\% from the 12.1 area\% of raw bio-oil, an increase of $87.0 \%$; this is due to the conversion of carboxylic acids to esters and ethers during the esterification reaction. The 11.59 area\% aldehydes of the raw bio-oil were decreased to 1.99 area\% for BF2. The ketones of raw bio-oil decreased from 24.23 area\% to 13.78 area\% for BF2. Phenols and other alcohols of raw bio-oil from 39.3 area\% increased to 46.77 area\% for BF2; this is due to presence of 1-butanol solvent approximately 34.12 area\% in the BF2. Phenol conversion was taken place from the 34.74 area\% of raw bio-oil to 11.58 area $\%$ for $\mathrm{BF} 2$, a decrease of $66.7 \%$. Other miscellaneous compounds of raw bio-oil from 2.92 area\% increased to 5.05 area\% for $\mathrm{BF} 2$.

BF2 fuel is an esterified bio-oil meant to be a boiler fuel. As shown in this section the major chemical compounds present in the boiler fuel are esters, ethers, ketones, phenols and alcohols. When combusted the product emissions are expected to water vapor, $\mathrm{CO}_{2}, \mathrm{CO}$, hydrogen, nitrogen and carbon soot. 
Table 2. Raw bio-oil and BF2 chemical composition analysis by GC-MS with area percentages.

\begin{tabular}{|c|c|c|c|}
\hline Raw bio-oil & & Boiler fuel (BF2) & \\
\hline Compound name & Area\% & Compound name & Area\% \\
\hline Acids & & Acids & \\
\hline Acetic acid & 5.1 & Hexanoic acid & 0.58 \\
\hline Heptanoic acid & 1.42 & $\begin{array}{l}\text { 5-Ethylcyclopent-1-ene-1-carboxylic } \\
\text { acid }\end{array}$ & 0.61 \\
\hline Benzoic acid, 4-hydroxy-3-methoxy- & 0.75 & Esters \& Ethers & \\
\hline Benzeneacetic acid, alpha-hydroxy- & 1.96 & Acetic acid, butyl ester & 8.99 \\
\hline benzeneacetic acid, 4-hydroxy-3-methyl & 0.54 & Oxalic acid, isobutyl nonyl ester & 1.36 \\
\hline Esters \& Ethers & & Propanoic acid, butyl ester & 3.04 \\
\hline acetic acid, 1-methylethyl ester & 1.82 & $\begin{array}{c}\text { Propanoic acid, 2-methyl-, butyl } \\
\text { ester }\end{array}$ & 0.77 \\
\hline acetic acid, fluoro-, ethyl ester & 1.93 & Butanoic acid, octyl ester & 2.69 \\
\hline pentanoic acid, ehtyl ester & 0.92 & Butyl 2-methylbutanoate & 0.68 \\
\hline n-heptyl hexanoate & 0.94 & Pentanoic acid, butyl ester & 1.82 \\
\hline Hexanoic acid, 1-methylhexyl ester & 1.85 & Valeric acid, 2-methyl- pentyl ester & 0.49 \\
\hline 1-propene, 1-methyoxy-2-methyl- & 0.93 & Hexanoic acid, butyl ester & 1.96 \\
\hline Furan, 2-ethoxy-2,3-dihydro-4-methyl & 0.58 & $\begin{array}{l}\text { 4-(N-Dimethylamino) phenol, } \\
\text { acetate }\end{array}$ & 0.83 \\
\hline 2,6-Dimethoxytoluene & 0.9 & Aldehydes & \\
\hline 3-methoxy-4-methylaniline & 1.25 & Benzaldehyde, 3, 4-dihydroxy & 1.99 \\
\hline 4,4'-Dimethoxy-biphenyl-2-carboxyl- & 0.98 & Ketones & \\
\hline Aldehydes & & 2-butanone, 3-methyl & 0.56 \\
\hline furfural & 1.94 & Cyclopentanone, 2-methyl & 2.51 \\
\hline 2-furancarboxaldehyde, 5-methyl- & 0.63 & 3-methyl cyclopentanone & 0.89 \\
\hline Glutaraldehyde & 1.16 & 2-heptanone & 0.88 \\
\hline cyclopentanecarboxaldehyde & 0.82 & Cyclohexanone, 3-dimethyl & 0.87 \\
\hline 2-Furancarboxaldehyde, 5-methyl- & 1.78 & Cyclohexanone, 2,3-dimethyl & 0.83 \\
\hline 5-methyl-2-thiophenecarboxaldehyde & 0.55 & Ethanone, 1-cyclohexyl & 0.58 \\
\hline vanillin & 1.39 & 2-cyclopenten-1-one, 2,3-dimethyl & 0.59 \\
\hline 9,12-octadecadienal & 0.6 & 2-cyclopenten-1-one, 3,4,4-trimethyl & 0.71 \\
\hline Benzaldehyde, 3-hydroxy-, oxime & 0.74 & $\begin{array}{l}\text { 3H-Pyrazol-3-one, 2,4-dihydro-5- } \\
\text { methyl }\end{array}$ & 0.65 \\
\hline 4-hydroxy-2-mehoxycinnamaldehyde & 0.71 & Cyclohexanone, 2-butyl & 1.08 \\
\hline 4-hydroxy-2-methylacetophenone & 1.27 & 4-Hepten-3-one, 4-methyl & 0.47 \\
\hline Ketones & & 2-propanone, 1-94-methoxyphenyl)- & 3.16 \\
\hline $\begin{array}{l}\text { 4H-Pyran-4-one, 3,5-dihydroxy-2- } \\
\text { methyl- }\end{array}$ & 0.58 & Alcohols & \\
\hline 2-propanone, 1-94-hydroxy-3-methoxy)- & 0.84 & 1-Butanol & 34.12 \\
\hline $\begin{array}{l}\text { 2-cyclopenten-1-one, 2-hydroxy-3- } \\
\text { methyl }\end{array}$ & 1.84 & Phenol & 0.71 \\
\hline 2-cyclopenten-1-one, 2-hydroxyl- & 1.42 & Phenol, 3-methyl & 0.54 \\
\hline Ethanone, 1-(4-hydroxy-3- & 19.55 & Phenol, 4-methyl & 2.59 \\
\hline
\end{tabular}




\begin{tabular}{|c|c|c|c|}
\hline methoxyphenol) & & & \\
\hline Alcohols & & Phenol, 2,4-dimethyl & 1.42 \\
\hline 2-Propanone, 1-hydroxy & 3.63 & Phenol, 4-propyl & 0.84 \\
\hline phenol, 2-methyl- & 1.14 & Phenol, 2-ethyl-6-methyl & 1.04 \\
\hline phenol, 4-methyl- & 0.72 & phenol, 4-butyl & 0.53 \\
\hline phenol, 2-methoxy- & 4.15 & phenol, 2-butyl & 0.52 \\
\hline 4-mercaptophenol & 0.59 & Phenol, 4-(1,1-dimethylpropyl)- & 0.78 \\
\hline Phenol, 2-methoxy-4-methyl- & 10.81 & Phenol, 2-methoxy-4-propy & 0.55 \\
\hline 1,2-Benzenediol, 3-methyl- & 0.93 & Phenol, 5-methoxy-2,3-dimethyl & 2.06 \\
\hline phenol, 4-ethyl-2-methoxy- & 2.61 & Ethanol, 2-(4-(1,1-dimethylpropyl) & 1.07 \\
\hline 1,2-Benzenediol, 4-methyl- & 1.31 & Other & \\
\hline Eugenol & 1.78 & 3-Undecene, 6-methyl- & 1.47 \\
\hline 1-propene, 1-methyoxy-2-methyl- & 0.93 & Cyclopropane, trimethylmethylene & 0.86 \\
\hline phenol, 2-methoxy-4-(1-propenyl)- & 1.65 & Cyclooctane & 0.74 \\
\hline Phenol, 2-methoxy-3-(2-propenyl)- & 3.28 & $\begin{array}{c}\text { Bicyclo[3.1.1] heptan-2-one, 6,6- } \\
\text { dimethyl }\end{array}$ & 0.61 \\
\hline $\begin{array}{c}\text { phenol, 2-methoxy-4-propyl- } \\
\text { homovanillyl alcohol }\end{array}$ & 3.16 & $\begin{array}{c}\text { 1-(cyclopropylmethyl)-4- } \\
\text { (methyloxyl) }\end{array}$ & 0.77 \\
\hline phenol, 2-methoxy-4-(methoxymethyl)- & 0.98 & Cyclopentane, 1,2,3,3,5-pentamethyl & 0.86 \\
\hline $\begin{array}{c}\text { Ethyl, 4-hydroxy-7-trifluoromethyl- } \\
\text { quinoline }\end{array}$ & & 1-Tyrophanamide & 0.51 \\
\hline Other & & & $\mathbf{7 8 . 9 3}$ \\
\hline T,4-anhydro-d-galactosan & 2.1 & & \\
\hline Butanenitrile, 4-(trichlorosilyl)- & 0.91 & & \\
\hline Total & $\mathbf{1 0 0}$ & & \\
\hline & & & \\
\hline
\end{tabular}

Table 3 compares viscosity and density within each aging period of BF2 aging at $80{ }^{\circ} \mathrm{C}$ for 6 , $12,18,24 \mathrm{~h}$. To estimate the stability of the boiler fuel produced in this method at accelerated aging test was performed at $80{ }^{\circ} \mathrm{C}$ over a $24 \mathrm{~h}$ period with viscosity tested at each $6 \mathrm{~h}$ intervals of aging time. All BF2 samples were stored in sealed vials and weighed before and after each aging period. Samples were heated in an aerated oven at $80{ }^{\circ} \mathrm{C}$ for $6,12,18$, and $24 \mathrm{~h}$. As shown in the Table 3 both untreated raw bio-oil and control BF2 specimens were tested without application of temperature. Viscosity of raw bio-oil was $12.0 \mathrm{cSt}$ and density was $1.2 \mathrm{~g} / \mathrm{ml}$. The BF2 untreated control specimen comprised $9.9 \mathrm{cSt}$ with density of $0.96 \mathrm{~g} / \mathrm{ml}$. The BF2 viscosity values replicates measured at $6,12,18,24 \mathrm{~h}$ respectively heating at $80{ }^{\circ} \mathrm{C}$ were $8.82,8.88,8.62$ and $9.10 \mathrm{cSt}$; density values for the same respective time periods were $0.95,0.95,0.94$ and $0.95 \mathrm{~g} / \mathrm{ml}$. The viscosity and density values observation indicates that esterified bio-oil produced has a lower viscosity and density compared to raw bio-oil. Further, this viscosity and density changes with over time as unchanged by the accelerated aging test results. 
Table 3. Comparison of viscosity and density within each aging period of $\mathrm{BF} 2$ at $80{ }^{\circ} \mathrm{C}$ for 6,12 , $18,24 \mathrm{~h}$ with control untreated raw bio-oil and BF2 at room temperature.

\begin{tabular}{|c|c|c|c|}
\hline Sample & Temp $\left({ }^{\circ} \mathrm{C}\right)$ & Viscosity $(\mathrm{cSt})$ & Density $(\mathrm{g} / \mathrm{ml})$ \\
\hline $\begin{array}{c}\text { Untreated } \\
\text { Raw bio-oil }\end{array}$ & Room temp $\sim 25$ & 12.0 & 1.2 \\
\hline $\begin{array}{c}\text { Control BF2 } \\
\text { BF2 @ 6 h }\end{array}$ & 80 & 9.9 & 0.96 \\
\hline BF2 @ 12 h & 80 & 8.82 & 0.95 \\
\hline BF2 @ 18 h & 80 & 8.88 & 0.95 \\
\hline BF2 @ 24 h & 80 & 8.62 & 0.94 \\
\hline
\end{tabular}

\section{Conclusions}

The objective of this study's comparison of oxidation pretreatments was to determine the most effective pretreatment, of those tested, for production of maximum yield of carboxylic acids. The increased production of carboxylic acids provides an increased degree of esterification with a relatively low percentage of alcohol (20\%). This led to production of a high HHV boiler fuel. Our approach of oxidation pretreatment of raw bio-oil with ozone $/ \mathrm{H}_{2} \mathrm{O}_{2}$ pretreatment followed by esterification successfully produced boiler fuel (BF2) with improved fuel properties and yields. In addition to ozone $/ \mathrm{H}_{2} \mathrm{O}_{2}$ pretreatment, ozone alone and $\mathrm{H}_{2} \mathrm{O}_{2}$ alone oxidation pretreatments were also investigated. Ozone $/ \mathrm{H}_{2} \mathrm{O}_{2}$ pretreatment was shown to perform a higher degree of raw bio-oil oxidation as measured by magnitude of AV attained. The AV of raw bio-oil after ozone $/ \mathrm{H}_{2} \mathrm{O}_{2}$ pretreatment was increased from 90.3 to $165.4 \mathrm{mg} \mathrm{KOH} / \mathrm{g}$. The boiler fuel (BF2) produced from the OPTBO product had an $\mathrm{HHV}$ of $35.3 \mathrm{MJ} / \mathrm{Kg}$; the energy density of boiler fuel produced by this method was increased by $120.62 \%$ from raw bio-oil of $16.0 \mathrm{MJ} / \mathrm{Kg}$. $\mathrm{BF} 2$ viscosity was reduced significantly to 10.1 compared to, BF1 value of 25.9 , a reduction of 156.4\%; the method of raw bio-oil pretreatment followed by esterification was reduced boiler fuel viscosity with a considerable amount. Oxygen content and acid value were reduced by $71.4 \%$ and $81.9 \%$, respectively. The esterification of OPTBO compared to esterification of raw bio-oil produced boiler fuel with improved characteristics in terms of lower viscosity, density, water content and HHV. The boiler fuel (BF2) from OPTBO also resulted in production of with $23 \%$ higher yield compared to boiler fuel (BF1) produced from direct raw bio-oil esterification.

\section{Acknowledgement}

This research is based upon work funded through the Sustainable Energy Research Center at Mississippi State University and is supported by the Department of Energy under Award number DE-FG3606GO86025.

\section{Disclaimer}

This report was prepared as an account of work sponsored by an agency of the United States government. Neither the United States Government nor any agency thereof, nor any of their employees, makes any warranty, express or implied, or assumes any legal liability or 
responsibility for the accuracy, completeness, or usefulness of any information, apparatus, product, or process disclosed, or represents that its use would not infringe privately owned rights. Reference herein to any specific commercial product, process, or service by trade name, trademark, manufacturer, or otherwise does not necessarily constitute or imply its endorsement, recommendation, or favoring by the United States Government or any agency thereof. The views and opinions of authors expressed herein do not necessarily state or reflect those of the United States Government or any agency thereof.

\section{References}

[1] Yan, J.; Alvors, P.; Eidensten, L. A future for biomass: Mechanical Engineering, 1997, 117, 94-98.

[2] Huber, G. W.; Iborra, S.; Corma, A. synthesis of transportation fuels from biomass: Chemistry, Catalysts and Engineering. Chem. Review, 2006, 106, 4044-4098.

[3] Mohan, D.; Pittman, C. U. Jr.; Steele, P. H. Pyrolysis of wood/biomass for bio-oil: A critical review. Energy \& Fuels, 2006, 20(2), 848-889.

[4] Bridgwater, A.V.; Peacocke, G.V. C. Fast pyrolysis processes for biomass: Renew Sustain Energy Rev, 2000, 4(1), 1-73.

[5] Czernik, S.; Bridgwater, A.V. Overview of applications of biomass fast pyrolysis oil: Energy \& Fuels, 2004, 18, 590-598.

[6] Diebold, J. P. A review of the chemical and physical mechanisms of the storage stability of the fast pyrolysis bio-oils: NREL/SR-570-27613, 2000, January.

[7] Hu, X.; Wang, D. M.; Gunawan, R.; Lievens, C.; Chaiwat, W.; Gholizadeh, M.; Wu, L.; Li, X.; Li, C. Z. Polymerization on heating up of bio-oil: A model compound study: Reaction Engineering, Kinetics and Catalysis, 2012, 59(3), 888-900.

[8] Junming, X.; Jianchun, J.; Yunjuan, S.; Yanju, L. Bio-oil upgrading by means of ethyl ester production in reactive distillation to remove water and to improve storage and fuel characteristic: Biomass and Bioenergy, 2008, 32, 1056-1061.

[9] Xu, J.; Jiang, J.; Dai, W.; Zhang, T.; Xu, Y. Bio-oil upgrading by means of ozone oxidation and esterification to remove water and to improve fuel characteristics: Energy \& Fuels, 2011, 25, 1798-1801.

[10] Gagnon, J.; Kaliaguine, S. Catalytic hydrotreatment of vacuum pyrolysis oil from wood: Industrial and Engineering Chemistry Research, 1988, 27, 1783-1788.

[11] Furimsky, E. Catalytic hydrodeoxygenation. Applied Catalysis A: 2000, 199, 147-190.

[12] Shanks, H. B.; Lohithrn, N. Upgrading of bio-oil: Effect of light aldehydes on acetic acid removal via esterification: Catalysis Communications, 2009, 11, 96-99.

[13] Elliot, D.C. Historical developments in hydroprocessing bio-oils. Energy \& Fuels, 2007, 21, 1792-1815.

[14] Weerachanchai, P.; Tangsathitkulchai, C.; Tangsathitkulchai, M. Effect of reaction conditions on the catalytic esterification of bio-oil: Korean J. Chem. Eng, 2012, 29(2), 182189.

[15] Wang, J.; Chang, J.; Fan, J. Catalytic esterification of bio-oil by ion exchange resins: Jounal of fuel chemistry and technology, 2010, 38, 5.

[16] Mahfud, F.H., Melian-Cabrera, I., Manurung, R.; Heeres, J.J. Biomass to fuels upgrading of flash pyrolysis oil by reactive distillation using a high boiling alcohol and acid catalysts, Process Safety and Environmental Protection, 2007, 85, 466-472. 
[17] Moens, L., Black, S.K., Myers, M.D.; Czernik, S. Study of neutralisation and stabilisation of a mixed hardwood oil, Energy \& Fuels, 2009, 23, 2695-2699.

[18] Xiong, W.M., Zhu, M.Z., Deng, L., Fu, Y.; Guo, Q.X. Esterification of organic acid in biooil using acidic ionic liquid catalyst, Energy \& Fuels, 2009, 23, 2278-2283.

[19] Tang, Y.; Yu, W.; Mo, L.; Lou, H.; Zheng, X. One-Step hydrogenation-esterification of aldehyde and acid to ester over bifunctional Pt catalysts: A model reaction as novel route for catalytic upgrading of fast pyrolysis bio-oil. Energy \& Fuels, 2008, 22, 3484-3488.

[20] Xu Ying, C. J., Zhang, Q.; Wang Tiejun, Wang Chenguang. Upgrading of bio-oil by esterification over solid base catalyst. Petrochemical Technology, 2010, 35(7), 615-618.

[21] Zhang, Q.; Chang, J., Wang, T-J.; Wu, C-Z.; Zhu, Xi-F. Study on upgrading of bio-oil catalyzed over solid acids. Journal of Fuel Chemistry and Technology, 2006, 34(6), 680684.

[22] Xiong, W-F.; Yao, F.; Lai, D-M.; Guo, Q-X. Upgrading of bio-oil via esterification catalysted with acidic ionexchange resin. Chemical Journal of Chinese Universities, 2009, 30(9), 1754-1758.

[23] Tang, Z.; Lu, Q.; Zhang, Y.; Zhu, X.; Guo, Q. One step bio-oil upgrading through hydrotreatment, esterification, and cracking. Industrial \& Engineering Chemistry Research, 2009, 48(15), 6923- 6929.

[24] Nkafamiya, I. I.; Maina, H. M.; Osemeahon, S. A.; Modibbo, U. U. Percentage oil yield and physiochemical properties of different groundnut species (Arachis hypogaea): African journal of food science, 2010, 4(7), 418-421. 
Figures:

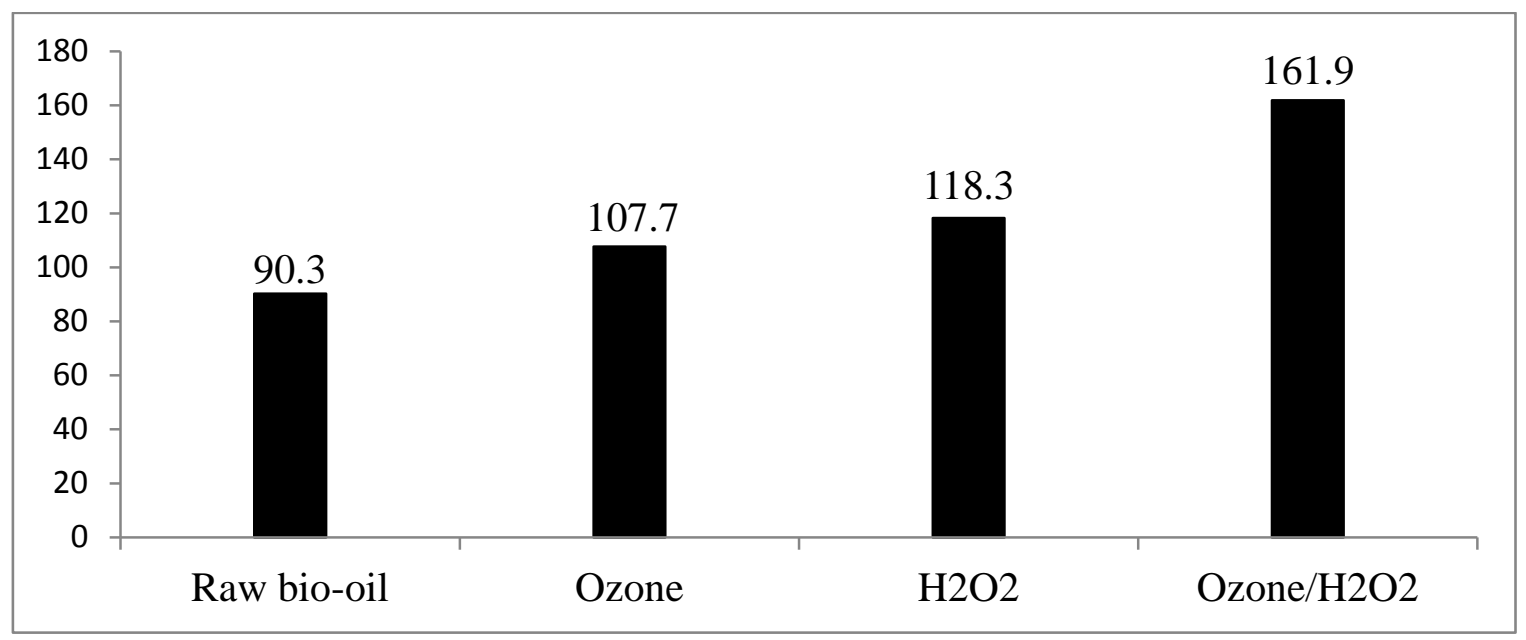

Fig. 1. Effect on $\mathrm{AVs}$ of ozone, $\mathrm{H}_{2} \mathrm{O}_{2}$ and combined ozone $/ \mathrm{H}_{2} \mathrm{O}_{2}$ oxidation pretreatments applied to raw bio-oil over a time period of $1 \mathrm{~h}$.

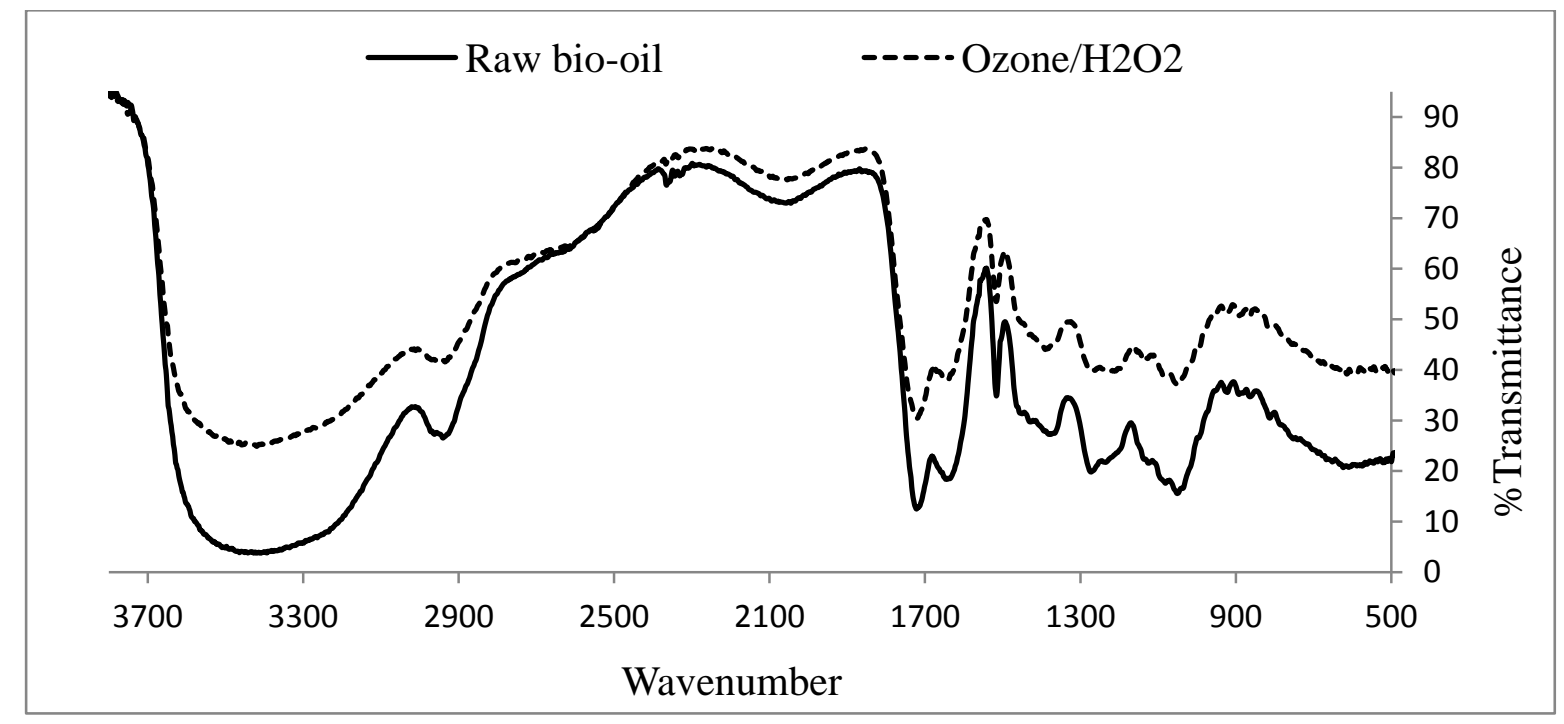

Fig. 2. FTIR spectrum comparison of raw bio-oil and ozone/ $\mathrm{H}_{2} \mathrm{O}_{2}$ pretreated product showing. 


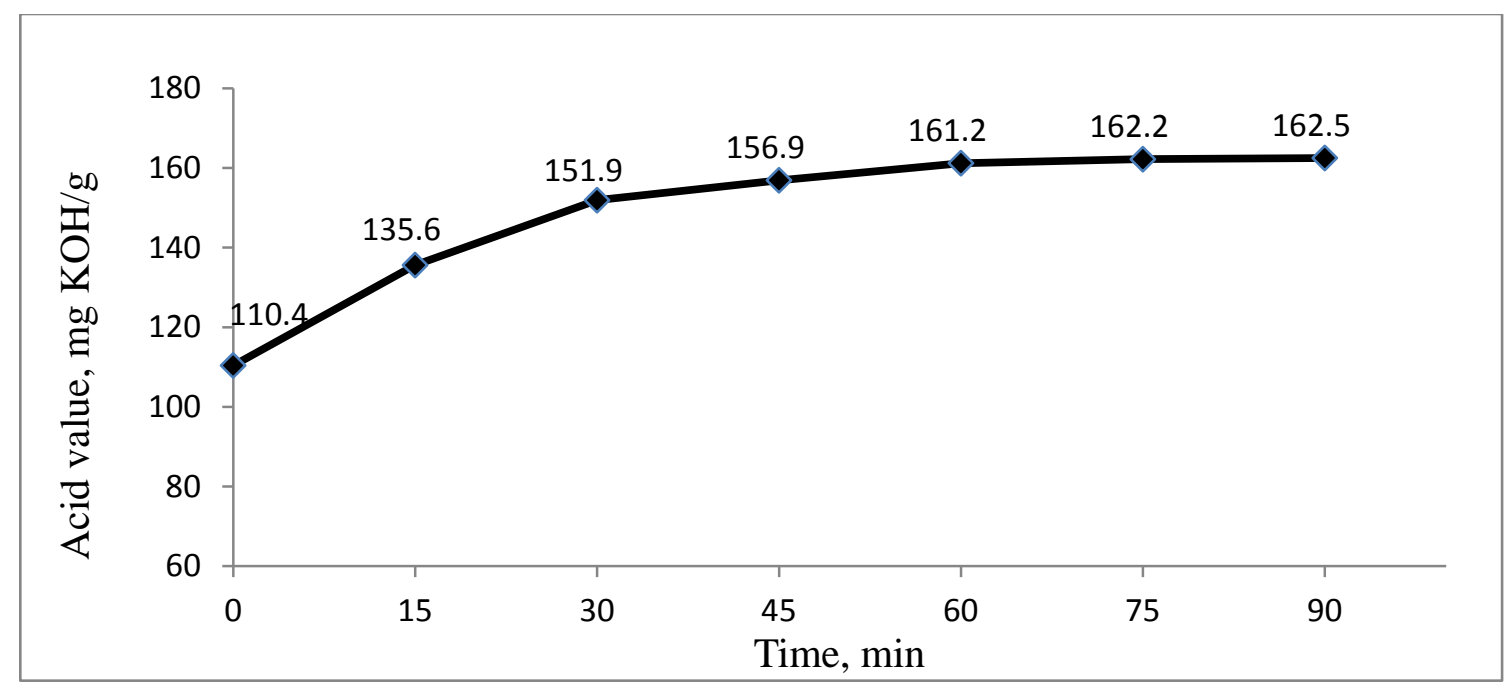

Fig. 3. Effect of ozone $/ \mathrm{H}_{2} \mathrm{O}_{2}$ pretreatment on $\mathrm{AV}$ of raw bio-oil over time as measured at 15-min intervals.

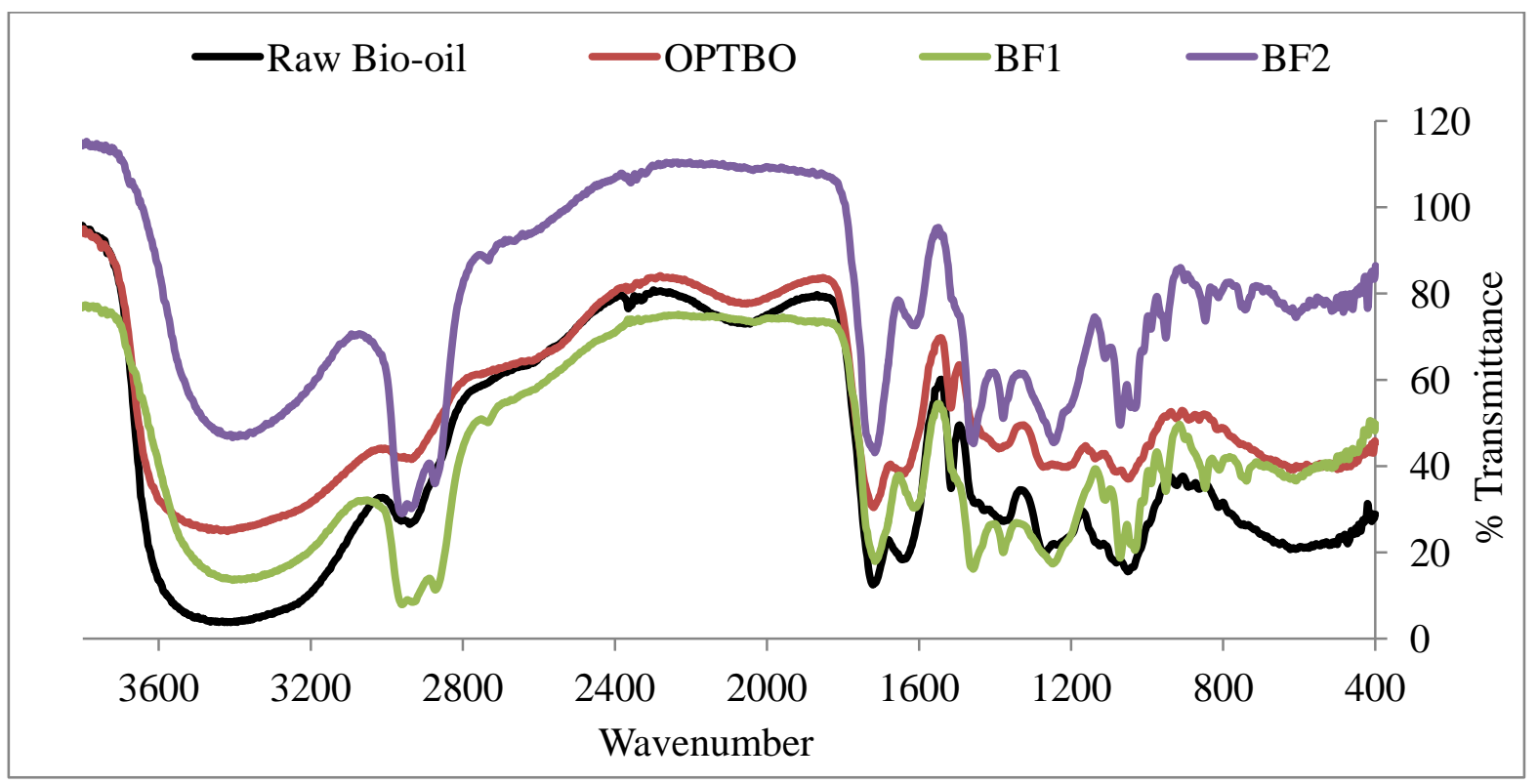

Fig. 4. FTIR spectra comparison between raw bio-oil, OPTBO, BF1 and BF2. 
Table 1. Comparison of some physical and chemical properties of raw bio-oil, OPTBO, BF1 and BF2.

\begin{tabular}{|c|c|c|c|c|}
\hline Properties & Raw bio-oil & OPTBO & BF1 & BF2 \\
\hline HHV, MJ/Kg & 16.0 & 16.4 & 33.4 & 35.3 \\
\hline AV (mg KOH/g) & 90.3 & 165.4 & 25.8 & 34.3 \\
\hline Water content (\%) & 30.4 & 33.5 & 4.6 & 3.6 \\
\hline Density, g/ml & 1.2 & 1.0 & 1.0 & 0.9 \\
\hline $\begin{array}{c}\text { Kinematic viscosity, } \\
40^{\circ} \mathrm{C}, \mathrm{cSt}\end{array}$ & 12.0 & 9.2 & 25.9 & 10.1 \\
\hline $\mathrm{pH}$ & 3.1 & 2.3 & 4.4 & 4.2 \\
\hline Elemental analysis (\%) & & & & \\
\hline $\mathrm{C}$ & 38.4 & 37.6 & 71.8 & 71.6 \\
\hline $\mathrm{H}$ & 7.6 & 7.6 & 9.8 & 10.3 \\
\hline $\mathrm{N}$ & 0.2 & 0.2 & 0.4 & 0.3 \\
\hline $\mathrm{O}$ & 53.7 & 54.6 & 17.9 & 17.7 \\
\hline Yield (wt\%) & - & - & 39.0 & 48.0 \\
\hline
\end{tabular}

Table 2. Raw bio-oil and BF2 chemical composition analysis by GC-MS with area percentages.

\begin{tabular}{|c|c|c|c|}
\hline Raw bio-oil & & Boiler fuel (BF2) & \\
\hline Compound name & Area\% & Compound name & Area\% \\
\hline Acids & & Acids & \\
\hline Acetic acid & 5.1 & Hexanoic acid & 0.58 \\
\hline Heptanoic acid & 1.42 & $\begin{array}{l}\text { 5-Ethylcyclopent-1-ene-1-carboxylic } \\
\text { acid }\end{array}$ & 0.61 \\
\hline Benzoic acid, 4-hydroxy-3-methoxy- & 0.75 & Esters \& Ethers & \\
\hline Benzeneacetic acid, alpha-hydroxy- & 1.96 & Acetic acid, butyl ester & 8.99 \\
\hline benzeneacetic acid, 4-hydroxy-3-methyl & 0.54 & Oxalic acid, isobutyl nonyl ester & 1.36 \\
\hline Esters \& Ethers & & Propanoic acid, butyl ester & 3.04 \\
\hline acetic acid, 1-methylethyl ester & 1.82 & $\begin{array}{c}\text { Propanoic acid, 2-methyl-, butyl } \\
\text { ester }\end{array}$ & 0.77 \\
\hline acetic acid, fluoro-, ethyl ester & 1.93 & Butanoic acid, octyl ester & 2.69 \\
\hline pentanoic acid, ehtyl ester & 0.92 & Butyl 2-methylbutanoate & 0.68 \\
\hline n-heptyl hexanoate & 0.94 & Pentanoic acid, butyl ester & 1.82 \\
\hline Hexanoic acid, 1-methylhexyl ester & 1.85 & Valeric acid, 2-methyl- pentyl ester & 0.49 \\
\hline 1-propene, 1-methyoxy-2-methyl- & 0.93 & Hexanoic acid, butyl ester & 1.96 \\
\hline Furan, 2-ethoxy-2,3-dihydro-4-methyl & 0.58 & $\begin{array}{l}\text { 4-(N-Dimethylamino) phenol, } \\
\text { acetate }\end{array}$ & 0.83 \\
\hline 2,6-Dimethoxytoluene & 0.9 & Aldehydes & \\
\hline 3-methoxy-4-methylaniline & 1.25 & Benzaldehyde, 3, 4-dihydroxy & 1.99 \\
\hline 4,4'-Dimethoxy-biphenyl-2-carboxyl- & 0.98 & Ketones & \\
\hline Aldehydes & & 2-butanone, 3-methyl & 0.56 \\
\hline furfural & 1.94 & Cyclopentanone, 2-methyl & 2.51 \\
\hline
\end{tabular}




\begin{tabular}{|c|c|c|c|}
\hline 2-furancarboxaldehyde, 5-methyl- & 0.63 & 3-methyl cyclopentanone & 0.89 \\
\hline Glutaraldehyde & 1.16 & 2-heptanone & 0.88 \\
\hline cyclopentanecarboxaldehyde & 0.82 & Cyclohexanone, 3-dimethyl & 0.87 \\
\hline 2-Furancarboxaldehyde, 5-methyl- & 1.78 & Cyclohexanone, 2,3-dimethyl & 0.83 \\
\hline 5-methyl-2-thiophenecarboxaldehyde & 0.55 & Ethanone, 1-cyclohexyl & 0.58 \\
\hline vanillin & 1.39 & 2-cyclopenten-1-one, 2,3-dimethyl & 0.59 \\
\hline 9,12-octadecadienal & 0.6 & 2-cyclopenten-1-one, 3,4,4-trimethyl & 0.71 \\
\hline Benzaldehyde, 3-hydroxy-, oxime & 0.74 & $\begin{array}{l}\text { 3H-Pyrazol-3-one, 2,4-dihydro-5- } \\
\text { methyl }\end{array}$ & 0.65 \\
\hline 4-hydroxy-2-mehoxycinnamaldehyde & 0.71 & Cyclohexanone, 2-butyl & 1.08 \\
\hline 4-hydroxy-2-methylacetophenone & 1.27 & 4-Hepten-3-one, 4-methyl & 0.47 \\
\hline Ketones & & 2-propanone, 1-94-methoxyphenyl)- & 3.16 \\
\hline $\begin{array}{l}\text { 4H-Pyran-4-one, 3,5-dihydroxy-2- } \\
\text { methyl- }\end{array}$ & 0.58 & Alcohols & \\
\hline 2-propanone, 1-94-hydroxy-3-methoxy)- & 0.84 & 1-Butanol & 34.12 \\
\hline $\begin{array}{l}\text { 2-cyclopenten-1-one, 2-hydroxy-3- } \\
\text { methyl }\end{array}$ & 1.84 & Phenol & 0.71 \\
\hline 2-cyclopenten-1-one, 2-hydroxyl- & 1.42 & Phenol, 3-methyl & 0.54 \\
\hline $\begin{array}{l}\text { Ethanone, 1-(4-hydroxy-3- } \\
\text { methoxyphenol) }\end{array}$ & 19.55 & Phenol, 4-methyl & 2.59 \\
\hline Alcohols & & Phenol, 2,4-dimethyl & 1.42 \\
\hline 2-Propanone, 1-hydroxy & 3.63 & Phenol, 4-propyl & 0.84 \\
\hline phenol, 2-methyl- & 1.14 & Phenol, 2-ethyl-6-methyl & 1.04 \\
\hline phenol, 4-methyl- & 0.72 & phenol, 4-butyl & 0.53 \\
\hline phenol, 2-methoxy- & 4.15 & phenol, 2-butyl & 0.52 \\
\hline 4-mercaptophenol & 0.59 & Phenol, 4-(1,1-dimethylpropyl)- & 0.78 \\
\hline Phenol, 2-methoxy-4-methyl- & 10.81 & Phenol, 2-methoxy-4-propy & 0.55 \\
\hline 1,2-Benzenediol, 3-methyl- & 0.93 & Phenol, 5-methoxy-2,3-dimethyl & 2.06 \\
\hline phenol, 4-ethyl-2-methoxy- & 2.61 & Ethanol, 2-(4-(1,1-dimethylpropyl) & 1.07 \\
\hline 1,2-Benzenediol, 4-methyl- & 1.31 & Other & \\
\hline Eugenol & 1.78 & 3-Undecene, 6-methyl- & 1.47 \\
\hline 1-propene, 1-methyoxy-2-methyl- & 0.93 & Cyclopropane, trimethylmethylene & 0.86 \\
\hline phenol, 2-methoxy-4-(1-propenyl)- & 1.65 & Cyclooctane & 0.74 \\
\hline Phenol, 2-methoxy-3-(2-propenyl)- & 3.28 & $\begin{array}{l}\text { Bicyclo[3.1.1] heptan-2-one, 6,6- } \\
\text { dimethyl }\end{array}$ & 0.61 \\
\hline phenol, 2-methoxy-4-propyl- & 3.16 & $\begin{array}{l}\text { 1-(cyclopropylmethyl)-4- } \\
\text { (methyloxyl) }\end{array}$ & 0.77 \\
\hline homovanillyl alcohol & 0.98 & Cyclopentane, 1,2,3,3,5-pentamethyl & 0.86 \\
\hline phenol, 2-methoxy-4-(methoxymethyl)- & 0.65 & 1-Tyrophanamide & 0.51 \\
\hline $\begin{array}{l}\text { Ethyl, 4-hydroxy-7-trifluoromethyl- } \\
\text { quinoline }\end{array}$ & 0.98 & Total & 78.93 \\
\hline \multicolumn{4}{|l|}{ Other } \\
\hline 3,4-anhydro-d-galactosan & 2.1 & & \\
\hline Butanenitrile, 4-(trichlorosilyl)- & 0.91 & & \\
\hline Total & 100 & & \\
\hline
\end{tabular}


Table 3. Comparison of viscosity and density within each aging period of $\mathrm{BF} 2$ at $80{ }^{\circ} \mathrm{C}$ for 6,12 , 18, $24 \mathrm{~h}$ with control untreated raw bio-oil and BF2 at room temperature.

\begin{tabular}{|c|c|c|c|}
\hline Sample & Temp $\left({ }^{\circ} \mathrm{C}\right)$ & Viscosity $(\mathrm{cSt})$ & Density $(\mathrm{g} / \mathrm{ml})$ \\
\hline $\begin{array}{c}\text { Untreated } \\
\text { Raw bio-oil }\end{array}$ & Room temp $\sim 25$ & 12.0 & 1.2 \\
\hline Control BF2 & Room temp 25 & 9.9 & 0.96 \\
\hline BF2 @ 6 h & 80 & 8.82 & 0.95 \\
\hline BF2 @ 12 h & 80 & 8.88 & 0.95 \\
\hline BF2 @ 18 h & 80 & 8.62 & 0.94 \\
\hline BF2 @ 24 h & 80 & 9.10 & 0.95 \\
\hline
\end{tabular}

